\title{
STOSUJ USTAWY I RÓB, CO CHCESZ? POJĘCIE NIEZAWISLOŚCI A DEONTOLOGICZNY MODEL CNÓT SĘDZIOWSKICH
}

\begin{abstract}
Streszczenie. W niniejszym artykule autorka rozważa niezawisłość sędziów w świetle modelu deontologii cnót. Analizuje ich decyzje i postawy w toku stosowania prawa, argumentując, że aspiracje, by realizować sędziowskie cnoty, mają charakter wtórny względem nadrzędnych wymogów przestrzegania prawa. Stawia tezę, że przestrzeń niezawisłości stanowi wyraz swoistego zaufania ustrojodawcy, iż sędziowie posiadają dyspozycje, które umożliwiają nie tylko wywiązywanie się z obowiązków, lecz także sprostanie wyzwaniom etycznym podczas orzekania. Przywołuje teorie orzekania w trudnych przypadkach autorstwa H. L. A. Harta i R. Dworkina oraz próbuje odpowiedzieć na pytanie, który z teoretycznych modeli - Hartowski czy Dworkinowski - lepiej charakteryzuje praktykę orzeczniczą polskiego wymiaru sprawiedliwości.
\end{abstract}

Słowa kluczowe: niezawisłość, deontologia, sędziowskie cnoty, teoria orzekania, Dworkin, Hart.

\section{WYKAZ SKRÓTÓW}

k.p.k. - ustawa z dnia 6 czerwca 1997 r. - Kodeks postępowania karnego (Dz. U. 1997, Nr 89, poz. 555). Konstytucja - Konstytucja Rzeczypospolitej Polskiej z dnia 2 kwietnia 1997 r. (Dz. U. 1997, Nr 78, poz. 483 ze zm.).

u.s.p. - ustawa z dnia 27 lipca 2001 r. - Prawo o ustroju sądów powszechnych (Dz. U. 2001, Nr 98, poz. $1070 \mathrm{ze} \mathrm{zm})$.

z.z.e.z.s. - Zbiór Zasad Etyki Zawodowej Sędziów. Załącznik do uchwały nr 16/2003 Krajowej Rady Sądownictwa z dnia 19 lutego 2003 r.

\section{WPROWADZENIE}

Nie ulega wątpliwości, że sędziowie, dokonując czynności orzeczniczych, podlegają określonym rygorom. Przede wszystkim obowiązani są stosować ustawy. Każda decyzja sędziego musi mieć właściwą podstawę prawną. Ponadto sędzia musi też sprostać wyzwaniom etycznym. Zarówno podczas sprawowania wymiaru sprawiedliwości, jak i poza siedzibą sądu powinien być bez zarzutu ${ }^{1}$.

*Uniwersytet Wrocławski, Katedra Teorii i Filozofii Prawa, anna-ro@wp.pl.

${ }^{1}$ Sędzia o nieskazitelnym charakterze powinien być bez zarzutu pod rygorem pociagnięcia do odpowiedzialności dyscyplinarnej: art. $61 \S 1$ pkt 2 u.s.p. 
Co oznacza owo „bycie bez zarzutu” podczas orzekania i jak rozumieć sens gwarantowanej sędziom przestrzeni „niezawisłości”?

Argumentuję, że deontologiczny model cnót (koncepcja deontologii cnót) może stanowić ciekawą perspektywę dla namysłu nad sensem pojęcia niezawisłego stosowania prawa. Przez deontologię cnót rozumiem normatywną koncepcję etyczną, która przyjmuje następującą formułę: czyn jest moralnie słuszny, jeśli był motywowany przez odpowiednią do sytuacji $S \rightarrow$ cnotę $C$ osoby spełniającej dany wzór osobowy (Saja 2015, 137). Teoria ta zakłada, że cnoty wchodzące w skład danego wzorca osobowego są wtórne względem wymogu przestrzegania określonych zasad postępowania i uzasadnione jako ważne dyspozycje do przestrzegania rygorów moralnych oraz respektowania praw innych osób. Przypomina rozróżnienie L. L. Fullera na moralność obowiązku i etykę aspiracji (Fuller $1969,5)$. Do tego rozróżnienia będę się odwoływać w dalszych rozważaniach ${ }^{2}$.

Stawiam tezę, że ustrojodawca dopuścił przestrzeń niezawisłości, ufając, iż niezależny sędzia będzie posiadał określone cnoty (realizował wzorzec osobowy), które umożliwią mu orientację w prawie i wskazywanie tego, co obowiązuje. Analizuję postawy niezawisłych sędziów, podejmujących określone decyzje, pod kątem wyzwań etycznych, jakie nieuchronnie wiążą się ze stosowaniem prawa.

Pragnę zastanowić się, co oznacza swoista przestrzeń wolności orzeczniczej niezawisłej judykatury ${ }^{3}$. Czy można ją scharakteryzować prawidłem: „Stosuj ustawy i rób, co chcesz"? Czy rozważanie pojęcia sędziowskiej niezawisłości z perspektywy koncepcji deontologii cnót może prowadzić do interesujących wniosków z punktu widzenia filozofii prawa?

W szczególności warto w tym względzie odnowić refleksję na temat znaczenia tzw. dyskrecjonalnej władzy sędziego, odwołując się do osi sporu H. L. A. Harta z R. Dworkinem (Hart 1961, 272). Celem niniejszego tekstu jest próba rozstrzygnięcia, który z teoretycznych modeli - Hartowski czy Dworkinowski - lepiej charakteryzuje praktykę orzeczniczą polskiego wymiaru sprawiedliwości.

\section{POJĘCIE NIEZAWISEEGO STOSOWANIA PRAWA}

Artykuł 178, ust. 1 Konstytucji podnosi, że „Sędziowie w sprawowaniu swojego urzędu są niezawiśli i podlegają tylko Konstytucji oraz ustawom”. W komentarzu do art. 178 Konstytucji, autorstwa W. Skrzydło, wyróżniono dwa aspekty tzw. os obistej niezawisłości każdego sędziego: pozytywny i negatywny

${ }^{2} \mathrm{Na}$ gruncie niniejszego tekstu będę posługiwać się zamiennie pojęciami: (1) moralność aspiracji i etyka cnót (traktując je jako zbliżone koncepcje aretologiczne); (2) moralność obowiązku i deontologia (traktując je jako teorie na temat obowiązku poszanowania pewnych zewnętrznych rygorów, norm, zasad).

${ }^{3} \mathrm{Z}$ pewnością kwestia, w jaki sposób sędziowie korzystają z ustawowych gwarancji niezawisłego sprawowania, wymaga osobnych badań. 
(Skrzydło 2013). Aspekt pozytywny uwzględnia wewnętrzną wolność sędziego (działanie na postawie prawa „,zgodnie ze swoim sumieniem i wewnętrznym przekonaniem”), zaś negatywny „oznacza niedopuszczalność wywierania na sędziego jakiegokolwiek nacisku z zewnątrz" (tamże). Sędziowska niezawisłość definiowana jest w sposób n e gaty wny poprzez odwołanie do szeregu gwarancji ustrojowych, takich jak: (1) wykluczenie kadencyjności; (2) zasada nieusuwalności sędziego z zajmowanego stanowiska; (3) ustanowienie immunitetu sędziowskiego; (4) zakaz przynależności do partii politycznych; (5) niepołączalność stanowiska sędziego ze sprawowaniem mandatu przedstawicielskiego poselskiego lub senatorskiego ${ }^{4}$. Takim (negatywnym) znaczeniem pojęcia niejednokrotnie posługuje się Trybunał Konstytucyjny: „Niezawisłość sędziowska oznacza wyłączenie jakiejkolwiek zewnętrznej ingerencji w proces sędziowskiego orzekania [...]" (K 8/99).

Gdy chodzi o p o zy ty w n y aspekt sędziowskiej niezawisłości - ten wydaje się pozostawać na drugim planie w dyskusji na temat niezawisłości, jako pewna mniej weryfikowalna dyspozycja członków wymiaru sprawiedliwości (K 3/98)5. $\mathrm{W}$ istocie pozytywny element odgrywa ważną rolę w konstrukcji tzw. sprzeniewierzenia się sędziowskiej niezawisłości'. Zgodnie z § 9 ust. 1 z.z.e.z.s.: „Sędzia nie może ulegać jakimkolwiek wpływom naruszającym jego niezawisłość, bez względu na ich źródło lub przyczynę".

Jak słusznie zauważył R. Hauser, „Poszanowanie i obrona [...] elementów niezawisłości są konstytucyjnym obowiązkiem wszystkich organów i osób stykających się z działalnością sądów, lecz także są konstytucyjnym obowiązkiem samego sędziego" (Hauser 2015). W podobnym duchu wypowiadał się w ostatnim czasie Trybunał Konstytucyjny (K 31/12) oraz Pierwszy Prezes Sądu Najwyższego S. Dąbrowski, który podkreślił, iż niezawisłość nie należy do przywilejów, lecz obowiązków sędziego. Prawo do niezawisłego sądu „to podmiotowe prawo publiczne obywatela" (Dąbrowski 2012, 13-14).

Odróżnienie dwóch wymiarów niezawisłości jest naturalną konsekwencją jej pojmowania jako pewnej gwarantowanej przestrzeni wolności. Wolność

${ }^{4}$ Poza wymienionymi gwarancjami - dodatkowe zabezpieczenie niezawisłego statusu stanowią gwarancje: (1) powoływania sędziów jedynie przez Prezydenta na wniosek Krajowej Rady Sądownictwa; (2) odpowiedniej sytuacji materialnej sędziów; (3) umocnienia roli i znaczenia samorządu sędziowskiego.

${ }^{5}$, ,[...] pozostałe elementy sędziowskiej niezawisłości mają wysoce subiektywny charakter [...] należąc do jego wewnętrznych przeżyć - do sumienia, nie poddają się [...] ocenie". Cytat pochodzi z pisma z 19 marca 1998 r. autorstwa Zarządu Głównego Zrzeszenia Prawników Polskich.

${ }^{6}$, ,[...] poszanowanie i obrona poszczególnych elementów niezawisłości są [...] także konstytucyjnym obowiązki em s a m e go sędzi e go. Naruszenie tego obowiązku może oznaczać sprzeniewierzenie się zasadzie niezawisłości sędziowskiej, a to jest równoznaczne $\mathrm{z}$ bardzo poważnym uchybieniem podstawowym zasadom funkcjonowania wymiaru sprawiedliwości” (K 3/98). 
negatywna, rozumiana jako wolność od przymusu (Berlin 1994, 183) 7 oraz wolność pozytywna (rozumiana jako pewna możność czy zdolność wyboru, wolność do czegoś) stanowią dwie - jednakowo ważne - strony medalu. Uwzględnienie takiego spojrzenia na pojęcie niezawisłości umożliwia określenie, jakie podmioty pozostają odpowiedzialne za zabezpieczenie niezawisłego charakteru orzekania. $Z$ jednej strony, na pewno są to ograny państwowe, zarówno przedstawiciele władzy wykonawczej, jak ustawodawczej. Z drugiej - kluczową odpowiedzialność za utrzymanie tzw. osobistej niezawisłości ponoszą sami sędziowie. Możliwość sprzeniewierzenia się sędziowskiej niezawisłości implikuje zakres wyzwań czy obowiązków, którym niezawisły sędzia winien sprostać (K 3/98).

Za jeden ważniejszych korelatów niezawisłości uważa się obowiązek bezstronności ${ }^{8}$. W piśmiennictwie prawniczym w różny sposób rozumie się tę przesłankę. Na gruncie niniejszego tekstu rozpatruję bezstronność jako ważną cechę sędziego (Tobor 2005, 4). Należy odróżnić w tym względzie rzec zywistą postawę sędziego w stosunku do wymagań etyki zawodowej, od pewnych g warancji ustroj ow y ch, mających na celu budowanie zaufania do instytucji sądownictwa (tamże). Wydaje się, że wymóg bycia bez zarzutu (,nieskazitelnego charakteru"9) na stanowisku sędziowskim sprowadza się w głównej mierze właśnie do ochrony zaufania bezstronności wymiaru sprawiedliwości. Z kolei obrona niezawisłości przez sędziego tyczy się konkretnego wysiłku sędziego, by wydać orzeczenie na podstawie obowiązujących norm, przedstawić możliwie najuczciwsze uzasadnienie decyzji sądowej (Tobor 2015,15$)^{10}$ oraz nie kierować się niedopuszczalnymi racjami (względami rodzinnymi, towarzyskimi, politycznymi itd.) podczas orzekania (Tobor 2005, 6). I chociaż wiedza o faktycznych motywacjach pozostaje dla stron najczęściej niedostępna, uzewnętrznione postawy sędziowskie wpływają na wizerunek wymiaru sprawiedliwości (tamże, 7$)^{11}$.

Podsumowując - pod pojęciem niezawisłości rozumiem gwarantowaną ustrojowymi rozwiązaniami sferę sędziowskiej wolności od zewnętrznych ingerencji (wolność od przymusu) oraz wolność w zakresie ustalenia i uzasadnienia podstawy rozstrzygnięcia (wolność decydowania), dopuszczoną jako wyraz swoistego

${ }^{7}$ „Przymus oznacza rozmyślne wtrącanie się innych ludzi w sferę mojego działania” (Berlin 1994, 183).

${ }^{8}$, ,[...] obowiązki sędziego wypełniać sumiennie, sprawiedliwość wymierzać zgodnie z przepisami prawa, bezstronnie według [...] sumienia" - to swoiste credo wymiaru sprawiedliwości, wpisane w treść roty sędziowskiego ślubowania.

${ }^{9}$ Por. art. 61, § 1, pkt 2 u.s.p.

${ }^{10}$ Problematyka „uczciwego” uzasadnienia decyzji sędziowskiej to temat na osobny artykuł.

${ }^{11}$ Z. Tobor wyodrębnił trzy sposoby wpływania poprzez postanowienia prawa na postawy sędziowskie: (1) przepisy zapewniające sytuację bezstronnego orzekania; (2) przepisy zakazujące podejmowania określonych aktywności poza salą rozpraw; (3) przepisy formułujące nakaz racjonalnego uzasadnienia wyborów i rozstrzygnięć, mieszczący się w akceptowalnym paradygmacie akceptowalnego uzasadnienia. 
zaufania ustrojodawcy, że niezależny sędzia będzie posiadał określone dyspozycje, które umożliwią mu orientację w prawie, niekierowanie się niedopuszczalnymi racjami i wskazywanie tego, co obowiązuje.

\section{NIEZAWISLOŚĆ A MORALNOŚĆ OBOWIĄZKU I ASPIRACJI}

Wolność niezawisłego sędziego ma charakter służebny względem obowiązku realizowania prawa jednostek do sądu. Niezawisłe sądownictwo nie jest ,powołane" do dowolnych rozstrzygnięć w sprawach jednostek, lecz do oddawania każdemu, co mu się - w sporze o prawo - od prawa należy oraz do promowania określonych wartości wspólnoty ${ }^{12}$.

W demokratycznym systemie prawnym niezawisły sędzia poddany jest pewnym rygorom etycznym. O jakie rygory etyczne chodzi?

Z. Tobor argumentuje, że zrozumiałe aspiracje sędziów do szczęśliwych zakończeń spraw na wokandzie powodują ,stałe napięcie w myśleniu sędziów: między - z jednej strony - ścisłym trzymaniem się przepisów (ze wszelkimi konsekwencjami) a - z drugiej - zrozumiałą skłonnością do »czynienia sprawiedliwości« w stosunku do ludzi, którzy przed nimi stoją" (Tobor 2015, 16). Myślę, że owo napięcie wynika z pewnego nieporozumienia; pojawia się wtedy, gdy sędziemu wydaje się, że nie jest w stanie sprostać sędziowskiej moralności aspiracji bez pogwałcenia moralności obowiązku.

Perspektywa deontologii cnót stara się łączyć te dwie niesprzeczne teorie normatywne, ukazując, iż aspiracje, by realizować cnoty wchodzace w skład danego wzorca osobowego mają służebny charakter względem nadrzędnych wymogów przestrzegania określonych zasad postępowania. I tak, sędziowie w pierwszej kolejności (w znakomitej większości przypadków ${ }^{13}$ ) powinni spełnić swój najbardziej podstawowy, konstytucyjny obowiązek wydania wyroku na podstawie właściwego przepisu ustawy, a nie posukiwać in nyla sposobów realizacji cnoty sprawiedliwości. L. Fuller zauważył, że moralność obowiązku formułuje ,zasadnicze reguły, bez których uporządkowane społeczeństwo dążące do określonych celów nie jest w stanie ich osiagnąć". Reguly, obowiązujące wszystkich sędziów bez wyjątku, wyznacza art. 61, § 1, pkt 2 u.s.p., który głosi, iż na stanowisko sędziego może być powołany ten, kto jest „nieskazitelnego charakteru". Przepis stanowi podstawę prawną egzekwowania dwóch

${ }^{12}$ Promowanie określonych wartości wspólnoty państwowej to raczej „stronniczość” w kierunku poszanowania aksjologicznego zaplecza systemów prawnych. Na przykład zasady: „umów należy dotrzymywać”, ,prawo nie działa wstecz”, ,ochrona dobrej wiary” stanowią wyraz moralnych przekonań społeczeństwa oraz budulec kultury prawnej.

${ }^{13}$ Piszę ,w znakomitej większości”, ponieważ zdarzają się przypadki, gdy sędzia musi rozważyć inne postawy, takie jak: otwarte odrzucenie prawa, złożenie rezygnacji z urzędu czy przełamanie znaczenia literalnego (Tobor 2015, 16-17). 
negatywnych obowiązków: (1) niedoprowadzania do oczywistej i rażącej obrazy przepisów prawa; (2) nieuchybiania godności urzędu. Domniemanie bycia bez zarzutu na stanowisku sędziowskim obowiązuje dopóty, dopóki sędzia nie zostanie obwiniony w postępowaniu dyscyplinarnym i pozbawiony koniecznego przymiotu ,nieskazitelnego charakteru” (Rocławska 2015, 103-104) ${ }^{14}$.

Jaką treść mają ,najbardziej minimalne” wymogi na stanowisku sędziowskim?

Bez wątpienia kluczowym zadaniem niezawisłego sędziego jest wydanie oznaczonej decyzji indywidualnej w sprawie. Pomimo możliwych trudności w ustaleniu stanu faktycznego i prawnego, sędziowie - stosując prawo - każdorazowo podejmują ten sam wysiłek: wybór przepisu, który stanie się podstawą prawną dla wywołania określonych skutków w sferze prawnej danej jednostki ${ }^{15}$. Orzekają w instytucjonalnych ramach, a najważniejszym ,przykazaniem” pozostaje dyrektywa: „Nie będziesz w oczywisty i rażący sposób obrażał przepisów prawa pod rygorem odpowiedzialności dyscyplinarnej"16.

Przesłanka nieuchybiania godności urzędu zawiera odniesienie do kategorii typowej dla moralności aspiracji. W istocie oznacza nakaz pewnej poprawności w zachowaniu, zarówno względem stron postępowania podczas ferowania wyroków, jak i poza salą rozpraw - w życiu codziennym. Chodzi o poszanowanie wzorca sędziego o „nieskazitelnym charakterze”, właściwego dla polskiej kultury prawnej ${ }^{17}$. Ponieważ brakuje sposobów, by zmusić człowieka, by zachowywał się na tyle doskonale, jak jest do tego zdolny oraz ponieważ niezwykle trudno jest wskazać niezawodne środki prowadzące do realizacji wzorów moralnych, moralność aspiracji zwraca się o operatywne wzorce kontroli „do swej krewniaczki etyki obowiązku” (Fuller 1969, 9). Moralność obowiązku „wychodzi od najniższego szczebla". Koncentruje się na pewnych minimalnych standardach i łatwych do zweryfikowania przewinieniach, które w oczywisty sposób w opinii sędziów są dyskredytujące dla obwinionego oraz mogą obniżyć wiarygodność wymiaru sprawiedliwości.

${ }^{14} \mathrm{Na}$ temat ustawowego wymogu nieskazitelności charakteru i skutków prawnych przypisania w postępowaniu dyscyplinarnym zarzutu - pisałam już wcześniej.

${ }^{15}$ Przyjmuję, że „odzwierciedleniem pojęcia stosowania prawa może być tylko model sylogistyczny” (Tobor 2015, 16).

${ }^{16}$ Chodzi tu m.in. o „naruszanie terminów sporządzania uzasadnień orzeczeń karnych”, „błędy w niezawisłym orzekaniu [...], tj. kwalifikowane bezprawie sądowe”, „oczywiste i rażące naruszenie przepisów prawa poprzez błędną wykładnię kwestii »niewiążących się bezpośrednio z samym orzekaniem «" (Rocławska 2015, 103).

${ }^{17}$ Do uchybień godności zawodu sędziego należą m.in. następujące zachowania: ,,prowadzenie w ruchu lądowym pojazdu mechanicznego w stanie nietrzeźwości”, ,powierzanie [...] sporządzenia opinii swemu mężowi”, „kontakt [...] ze stroną postępowania sądowego, w którym zasiada on w składzie sądu, poza salą rozpraw [...]”, ,popełnienie [...] umyślnego przestępstwa”, ,podejmowanie działań finansowych, które mogą być odebrane jako wykorzystywanie własnej pozycji” (Rocławska 2015, 103). 


\section{SĘDZIOWSKIE DECYZJE I CNOTY}

Niezawisły sędzia, zmierzając do wydania określonej decyzji indywidualnej, podejmuje szereg działań. Owe działania mogą mieć źródło w obowiązku lub też mogą być podejmowane jako wyraz pewnej dodatkowej, dopuszczalnej przez prawo, aspiracji. Klasyfikuję zatem sędziowskie zachowania w zależności od tego, czy prawo nakłada na judykaturę dany obowiązek, czy też przewiduje pewną swobodę postaw i decyzji, mieszczących się jednak w instytucjonalnych ramach $^{18}$.

Przedstawiam analizę niektórych postaw sędziów w toku niezawisłego stosowania prawa, pod kątem opisu wyzwań etycznych, z jakimi sądy muszą się mierzyć oraz wskazania przykładowych cnót moralnych i intelektualnych, jakie sędzia powinien posiadać:

1) rozpatrzenie sprawy bez nieuzasadnionej zwłoki,

2) decyzja interpretacyjna,

3) wyrafinowana argumentacja i uzasadnienie,

4) decyzja o przełamaniu znaczenia literalnego,

5) zgłoszenie zdania odrębnego.

\subsection{Rozpatrzenie sprawy bez nieuzasadnionej zwloki}

Nie ulega wątpliwości, że do koniecznych dyspozycji moralnych sędziów należy termin ow ość w wykonywaniu powierzonych im zadań. Umiejętność dotrzymywania terminów wiąże się z cechą skrupulatności. Osoba, która nie traktuje poważnie swoich obowiązków, raczej nie sprosta wyzwaniom urzędu. Nie znaczy to jednak, że nie występuje pewien margines tolerancji dla ,nieskazitelnych" sędziów opieszale uzasadniających wydane orzeczenia.

„Praktyka kolejnych przedłużeń terminów dospoząd zenia uzasadnienia bez podjęcia nawet próby kontroli powodów niedotrzymania dotychczas zakreślonego terminu jest nie do zaakceptowania. [...] Z uwagi na brak prawomocnego rozstrzygnięcia $\mathrm{w}$ sprawie pozostaje nadal $\mathrm{w}$ niepewności co do swojej sytuacji prawnej, a sporządzanie pisemnego uzasadnienia wyroku przez okres przeszło 6 miesięcy czas trwania tego stanu niepewności w sposób nieuzasadniony wydłużył" (II S 13/14). W cytowanej w orzeczeniu sprawie przed Sądem Okręgowym skarga na przewlekłość postępowania okazała się jedynie częściowo zasadna ${ }^{19}$.

${ }^{18}$ Przeprowadzenie jednoznacznej demarkacji pomiędzy tym, co obowiązkowe i wykraczające poza tę sferę może przysporzyć pewnych trudności. Podział ten jest oczywiście nieostry.

19 „Analizując przebieg postępowania karnego prowadzonego w sprawie oskarżonego W. B., począwszy od dnia 17 maja 2012 r., stwierdzić należy, iż do wydania merytorycznego rozstrzygnięcia terminowość i prawidłowość czynności podjętych przez Sąd Okręgowy w C. nie budzi zastrzeżeń” (II S 13/14). 


\subsection{Decyzja interpretacyjna}

Właściwe odczytanie tekstu prawnego to każdorazowe wyzwanie dla orzekającego sędziego. Co do zasady przepisy mają swoje znaczenia nadane przez dyskurs prawniczy i stanowią podstawę prawną w przewidzianych przez wspólnotę interpretacyjną sytuacjach. Czasami jednak zdarza się, że tekst prawny nie jest lub przestaje być z jakichś powodów jasny i wymaga od sędziów p o s taw y interpretacyjnej.

$\mathrm{Z}$ sędziowską decyzją interpretacyjną mamy do czynienia, gdy w toku stosowania prawa pojawia wątpliwość co do wyrażonej tekście prawnym intencji ustawodawcy i sędzia postanawia ją zrekonstruować (Tobor 2013, 39-40). Interpretacja przepisów wymaga opowiedzenia się przez interpretatora po stronie takiego rozumienia interpretowanego przepisu, za którym stoi najwięcej dowodów świadczących o intencji ustawodawcy.

„Interpretacja oparta wyłącznie na literalnym brzmieniu art. $186 \S 1$ k.p.k. i użytego tam sformułowania »zeznanie« znana jest tut. Sądowi [...]. Kłóci się ona jednak z ratio legis powołanego przepisu, czyniąc objęty nim zakaz często iluzorycznym (jak w rozpoznawanej sprawie), a nadto może tworzyć oczywistą pokusę obchodzenia go przez organy ścigania" (II AKa 509/13). Sąd postanowil dokonać odmiennej interpretacji słowa „zeznanie” od tej, którą przedstawił Sąd Najwyższy, odwołując się do celu regulacji art. 186 § 1 k.p.k.

Jakie cechy moralne powinien posiadać sędzia - interpretator? Przede wszystkim powinien być d o c i ek li w y. Rzetelna rekonstrukcja intencji ustawodawcy nie może odbywać się „na skróty”, z pominięciem pewnych łatwo dostępnych źródel, jakimi mogą być chociażby materiały legislacyjne (Bielska-Brodziak 2012, 144-153). Poza tym decyzja interpretacyjna niejednokrotnie stanowi akt o dwagi, zwłaszcza wtedy, gdy przychodzi sędziom - podobnie jak stało się w cytowanej sprawie - przełamać dotychczasową linię orzeczniczą sądu instancyjnie wyższego.

Wreszcie, wykładnia prawa wymaga pewnych zdolności intelektualnych (cnót intelektualnych) ${ }^{20}$, takich jak wiedza (prerozumienie intelektualne), kreatywność, inteligencja olaz mądrość życiowa (znajomość kontekstów, dla których interpretowana norma miałaby wywoływać skutki prawne). Bez tych ostatnich cech postawiona teza interpretacyjna pozostanie nieprzekonująca dla prawniczej wspólnoty interpretacyjnej, a poddany wykładni przepis może ponownie stać się przedmiotem ożywionych interpretacji. Należy pamiętać, że interpretatio cessat in claris.

${ }^{20}$ Lawrence Solum odróżnia za Arystotelesem jurydyczne cnoty moralne (odwaga, dociekliwość, sprawiedliwość i inne) od jurydycznych cnót intelektualnych (inteligencja - intelligence, uczoność - learnednes, mądrość - sophia, mądrość życiowa - phronesis lub pratical wisdom) (Solum 2006, 65-105). 


\subsection{Kwestia argumentacji i jakości uzasadnień}

L. Fuller przyrównuje moralność obowiązku do zasad gramatyki, zaś moralność aspiracji - do wyrafinowanego stylu (Fuller 1969, 6). O ile bez poszanowania reguł gramatyki nie można stworzyć poprawnego tekstu, o tyle bez pewnej pracy nad udoskonaleniem sposobu wypowiedzi, bez poszerzania horyzontów wyobraźni trudno napisać naprawdę dobrą sztukę. R. Dworkin, nawiązując do „wyśmiewanej" analogii pomiędzy sztuką i życiem, formułuje tezę, że prawie każdą aktywność życiową można rozwijać w kontekście artystycznym, twórczym ${ }^{21}$. Postawa twórcza, krytyczna, refleksyjna, argumentacyjna wnajlepszym wydaniu to także wyzwanie dla każdego sędziego (Dworkin 1986, 413).

Zgodnie z przepisami, sędziowie obowiązani są uzasadniać orzeczenia kończące postępowanie w sprawie, podając główne motywy rozstrzygnięcia. Nie zawsze powody rozstrzygnięcia są oczywiste dla stron postępowania, zatem podstawowe zdolności argumentacyjne i retoryczne stanowią jedne z ważniejszych dyspozycji intelektualnych wymiaru sprawiedliwości. O ile jednak każdy sędzia musi uczynić zadość wymogowi sporządzenia uzasadnienia swojej decyzji w przewidzianym terminie (ważne też, by nie uchybił obowiązkom, które wynikają z prawa jednostki do sądu i przepisów procesowych), o tyle cała reszta zależy od jego osobistych talentów i aspiracji.

R. Dworkin podkreśla zarówno etyczny, jak i estetyczny wymiar sędziowskiej argumentacji. Refleksyjne podejście do prawa umożliwia bowiem świadome uczestnictwo we wspólnocie politycznej, a w konsekwencji - ,a best route to the better future" (tamże).

\subsection{Decyzja o przelamaniu znaczenia literalnego}

Zdarzają się sytuacje, gdy zastosowanie językowo jasnego przepisu prowadzi do nieakceptowanych konsekwencji w danym porządku prawnym (Tobor 2013, 134-136). Językowe (tzw. literalne) znacznie przepisu wydaje się niezamierzone przez prawodawcę, gdyż istnieją poza tekstem prawnym inne dowody na intencję ustawodawcy w prawniczej wspólnocie interpretacyjnej.

„Wolno odstapić od znaczenia literalnego danego przepisu, gdy znaczenie to pozostaje w oczywistym konflikcie lub sprzeczności ze znaczeniem innych norm systemu, gdy prowadzi do absurdalnych konsekwencji, rozstrzygnięć pozostających w oczywistej sprzeczności z powszechnie akceptowanymi normami, zasadami sprawiedliwości i słuszności" (V ACa 251/13)22.

${ }^{21}$ Argumentuje, że: „The analogy between art and life has often been drawn and as often ridiculed. We should live our lives, the Romantics said, as a work of art [...]" (Dworkin 2011, 196).

${ }^{22}$, ,[...] w doktrynie [...] prezentowana jest wykładnia $\S 4$ art. 819 k.c., która odbiega od literalnego brzmienia tego przepisu. Dotyczy to zdania drugiego $\S 4$ art. 819 k.c. [...]”. 
Zdolność do przełamania nieakceptowanego znaczenia literalnego świadczy m.in. o posiadaniu przez sędziego (abstrahując od innych dyspozycji) niezwykle cennej cnoty intelektualnej- mądrości praktycznej (phronesis), tj. wiedzy o środkach prowadzących do celu. Dobry sędzia musi posiadać mądrość praktyczną, by promować właściwe cele i wybierać właściwe środki prawne. Jak zauważył L. Solum, „the good judge must possess practical wisdom in the choosing of legal ends and means" (Solum 2006, 84-85). Decyzja o przełamaniu znaczenia literalnego pojawia się jako konsekwencja dostrzeżenia, że tekst prawny zupełnie wyjątkowo nie prowadzi do ustalenia intencji prawod a w c y, n p z powodu błędu legislacyjnego. Sędzia może wtedy oznaczyć intencję prawodawcy na podstawie innych niż tekst prawny materiałów (dostępnych środków do celu).

\subsection{Zgłoszenie zdania odrębnego}

Możliwość zastrzeżenia votum separatum przy składaniu podpisu pod kolegialnym orzeczeniem sądowym to przejaw ustrojowego zabezpieczenia wo 1 ności do decydowania i samodzielnego myślenia niezawisłej judykatury.

W przypadkach, gdy orzeczenie o tym, co obowiązuje, staje się sporne nie tylko (ze zrozumiałych względów) dla stron postępowania, lecz także dla podmiotów od lat zanurzonych w kulturę prawną i drobiazgowo obeznanych z prawem, ustawodawca dopuszcza uzewnętrznienie odmiennego od przegłosowanego (wiążącego strony) sposobu rozumowania o prawie. Ze zdaniami odrębnymi najczęściej mamy do czynienia w trudnych przypadkach, tj. wtedy, gdy tekst prawny nie zawiera rozstrzygających reguł, a sprawa domaga się rozstrzygnięcia i opowiedzenia za konkretnymi wartościami.

Wydaje się, że zdolność do demaskacji innego niż większość poglądu zawsze wymaga odwagi, poza wyżej wymienionymi c notami intelektualnymi, nawet w tych mniej skomplikowanych sprawach (III AUa 915/12): „Nie zgadzam się z rozstrzygnięciem, uważam że apelacja powinna być oddalona”.

\section{TRUDNE PRZYPADKI}

W jaki sposób sędziowie korzystają z ustawowych gwarancji niezawisłego sprawowania urzędu w tzw. trudnych przypadkach, gdy reguły zawarte w aktach prawodawczych nie dają jasnej odpowiedzi na pytanie: co obowiązuje? Czy rzeczywiście w niektórych sytuacjach, ,parafrazując" słynne stwierdzenie św. Augustyna ${ }^{23}$, odpo-

${ }^{23}$ Odwołuję się do formuły: „Kochaj i rób, co chcesz” (Dilige, et quod uis fac), http://www. augustinus.it/latino/commento_1sg/omelia_07_testo.htm [dostęp 30.01.2016]. 
wiednia staje się formuła względem poczynań niezawisłego sędziego: „Stosuj ustawy i rób, co chcesz"? A jeśli tak, to na czym polega owa swoboda/wolność orzecznicza?

Poprawna teoria orzekania $\mathrm{w}$ trudnych przypadkach stanowi oś sporu dwóch najbardziej wpływowych teoretyków i filozofów prawa ostatnich dekad. H. L. A. Hart i R. Dworkin prowadzą w odmienny sposób niezwykle staranną narrację na ten sam temat.

H. L. A. Hart dowodzi, że w przypadkach niezdeterminowanych sędzia tworzy prawo (make law for the case), zamiast je stosować (applying pre-existing settled law) (Hart 1961, 272). Podkreśla, że istnieją dwa różne etapy procesu decyzyjnego: pierwszy, w którym sędzia odkrywa, że istniejące prawo nie dyktuje jakiejkolwiek decyzji, i drugi, w którym odchodzi od istniejącego prawa, by stworzyć prawo dla stron zgodnie ze swoją ideą tego, co dla stron najlepsze (Hart 2014, 5). Hart argumentuje, że istnieje wiele konkurencyjnych niedeterminowanych prawem rozstrzygnięć zależnych od sędziowskiego uznania (judicial discretion) (Hart 1961, 272). Sędzia ma wtedy nieuniknione zadanie prawotwórcze (Hart 2014, 11). Tworzy prawo, ważąc racje przemawiające za różnymi dopuszczalnymi rozstrzygnięciami, w kontekście tego, co on sam uważa za słuszne, ponieważ na płaszczyźnie prawnej wiele spraw może być uregulowanych w różny sposób.

Tymczasem R. Dworkin zaznacza, że w owych trudnych przypadkach (hard cases) zdolności poznawcze sędziów mogą być decydujące dla sprostania wyzwaniom orzeczniczym. Zintegrowana koncepcja prawa wymaga od sędziów, by ci podjęli wysiłek rozważenia w najlepszy możliwy sposób wszystkich istniejących możliwości zastosowania zasad w celu udzielenia jedynej słusznej odpowiedzi w trudnym przypadku (one right answer). Sędzia polega na poprawności swego rozumowania w trudnych przypadkach, zmierzając do „herkulesowego" osądu: którą z praktyk społecznych można najlepiej uzasadnić w świetle obiektywistycznej teorii moralności (tamże). W przypadkach gdy akt prawodawczy nie dostarcza jednoznacznych reguł postępowania, sędzia odszukuje (rekonstruuje) prawo przy pomocy innych dostępnych mu narzędzi - przede wszystkim wiedzy o wartościach wspólnoty politycznej, z której się wywodzi.

Tylko pozornie wydaje się, że można rozpatrywać każdą z osobna - zarówno pozytywistyczna, jak i antypozytywistyczną teorię orzekania - jako teorię pozwalającą uzasadnić konieczność doskonalenia się na stanowisku sędziowskim w celu sprostania prawu i wskazywania obowiązujących norm. W koncepcji Hartowskiej trudne przypadki (a więc te generujące największe wyzwania względem niezawisłej judykatury) stwarzaja przestrzeń dla wolności orzeczniczej, rozumianej jako prawotwórstwo. Sędzia rozpatruje „za” i „przeciw” określonym wyborom, ale jego decyzja finalna nie jest determinowana żadnym postanowieniem normatywnym. Natomiast Dworkinowska teoria zakłada, że pojęcie prawidłowego rozstrzygnięcia presuponuje możliwość jego ustalenia na podstawie obowiązujących norm. I jako taka zaleca posiadanie cnót jurydycznych - nie tyle dla samego 
rozwoju członków wymiaru sprawiedliwości, ile w celu bardziej efektywnego wskazywania prawa, zwłaszcza w trudnych przypadkach.

Teoria argumentująca, że cnoty uzasadnione są jako ważne dyspozycje do przestrzegania rygorów moralnych i respektowania praw innych osób, zwana deontologicznym modelem cnót, odpowiada tylko jednej z wyżej scharakteryzowanych teorii orzekania, czyli teorii Ronalda Dworkina. Dlaczego?

Ponieważ porównywane teorie orzekania $\mathrm{w}$ trudnych przypadkach mają związki z odmiennymi normatywnymi teoriami etycznymi. Moim zdaniem antypozytywistyczna teoria orzekania R. Dworkina rzeczywiście wspiera model deontologiczny (Galewicz 2013, 44-45), w którym obowiązki sędziego są ufundowane na pojęciu szacunku dla jednostki i tezy o rygorach deontycznych (La Torre $2007,66)^{24}$. Z kolei Hartowski pozytywizm prawniczy zdecydowanie odżegnuje się od założenia pewnych obiektywnych zasad systemu prawa - rygorów, które miałyby krępować judykaturę $w$ sytuacjach niezdeterminowanych przez istniejące akty prawodawcze. W trudnych przypadkach prawo nie dyktuje rozstrzygnięć: ostatecznie liczą się rachunki porównywalnych zysków/strat lub subiektywne argumenty „Za”/,przeciw” ochronie niewspółmiernych wartości państwa prawa (Hart 2014, 5). Niezawiśli sędziowie, który stają w obliczu trudnych spraw, mogą mieć różne zdanie na temat tego, co znaczy „słuszny wyrok”.

\section{PODSUMOWANIE - STOSUJ USTAWY I RÓB, CO CHCESZ?}

Konkludując, uważam, że w świetle charakterystyki ważniejszych obowiązków i wyzwań moralnych polskiego wymiaru sprawiedliwości lepsze uzasadnienie dla praktyki sądowego stosowania prawa dostarcza model Dworkinowski. Konstytucyjny obowiązek wydania wyroku na podstawie właściwego przepisu ustawy nie dopuszcza innej niż Dworkinowska narracji, nawet w trudnych przypadkach. Każde orzeczenie posiada swoiste roszczenie do bycia wiążącym (prawomocnym) twierdzeniem w oparciu o uprzednio ustanowione prawo.

Co robią sędziowie, zmierzając do wydania orzeczenia? I jaki posiadają zakres „wolności orzeczniczej” (wolności decydowania)?

Niezawiśli arbitrzy posiadają wolność decydowania po to, by wskazywać to, co obowiązuje i świadomie współtworzyć pewną wspólnotę wartości. Stosują przepisy prawa jako aktywni uczestnicy prawniczej wspólnoty interpretacyjnej (dyskursu prawniczego). W łatwych przypadkach stosują przepisy o ustalonym przez dyskurs znaczeniu, zaś gdy tekst prawny wymaga przyjęcia postawy interpretacyjnej, sędziowie rekonstruują intencję prawodawcy na podstawie wszystkich dostępnych źródeł. W trudnych przypadkach judykatura nie jest związana tekstem, który prowadzi do nieakceptowanych konsekwencji, co

${ }^{24}$ „As a matter of fact, 'integrity' is the discursive translation of a deontological model of judicial virtues, 'Justice Hercules', previously proposed by Dworkin himself' (La Torre 2007, 66). 
nie oznacza jednak braku związania normą prawną. Sędzia, wyposażony w konieczne cnoty intelektualne i moralne, winien szukać dowodów na intencję prawodawcy w innych źródłach (np. materiałach legislacyjnych). Bez posiadania pewnych niezbędnych cnót moralnych (odwaga, dociekliwość, terminowość, sumienność, sprawiedliwość) oraz intelektualnych (inteligencja, mądrość, mądrość życiowa - phronesis, kreatywność, zdolności argumentacyjne) nie uda się sędziemu prawidłowo wywiązywać z najbardziej podstawowych obowiązków. Nie zdoła on też podjąć wyzwań, które w nieuchronny sposób wiążą się ze stosowaniem prawa w sądzie (przełamanie linii orzeczniczej, dobre uzasadnienie, decyzja o przełamaniu znaczenia literalnego, zgłoszenie zdania odrębnego).

Za jedno z ważniejszych wyzwań judykatury uznałam orzekanie w sytuacji, gdy tekst prawny nie dostarcza jasnej odpowiedzi na pytanie o treść prawa. W trudnych przypadkach sposób rozumienia wolności orzeczniczej (wolności decydowania) ma szczególną doniosłość. W filozofii prawa istnieją dwa modele teoretyczne, dowodzące, dlaczego możliwe są różne odpowiedzi na pytanie o prawo w trudnych przypadkach:

1. H. L. A. Hart szuka przyczyn w naturze samego prawa, które uznaje za niezupełne oraz częstokroć ufundowane na wartościach o równych statusach lub wręcz całkowicie niewspółmiernych. Gdy te w trudnych przypadkach wchodzą w konflikt, a prawo nie preferuje jednoznacznie żadnej z nich, na sędzi spoczywa odpowiedzialność wyboru zgodnie osobistymi preferencjami.

2. R. Dworkin twierdzi, iż brak tylko jednej odpowiedzi na pytanie o prawo pochodzi z niedoskonałości aparatów poznawczych członków judykatury. Nie można z góry zakładać, że prawo nie zawiera jednej odpowiedzi, gdyż jest to postawa negatywnego dogmatyzmu epistemologicznego. Sędzia może być sceptyczny względem wskazywanych kryteriów tego, co obowiązuje; jednak w istocie zawsze tylko stosuje prawo, a nie je tworzy.

W ramach tzw. modelu deontologii cnót sędziowskich nie znajduje podstawy teza H. L. A. Harta o dyskrecjonalności w trudnych przypadkach, tak silnie podkreślająca autonomię niezawisłych sędziów. Teoria orzekania autorstwa R. Dworkina, nie rozstrzygając w tym miejscu o jej poprawności, przedstawia uzasadnienie praktyki orzeczniczej, które jest bliższe deontologicznemu modelowi cnót ${ }^{25}$. Cnoty jurydyczne mają pomóc judykaturze stać na straży absolutnych wartości wspólnoty politycznej - być „ludźmi zasad”.

${ }^{25} \mathrm{~W}$ dyskursie etycznym przypisuje się Dworkinowi przekonanie, że obiektywnie istnieją takie wartości, których należy bezwzględnie strzec (Galewicz 2013, 48). 


\section{BIBLIOGRAFIA}

Berlin, Isaiah. 1994. Cztery eseje o wolności. Warszawa: Wydawnictwo Naukowe PWN.

Bielska-Brodziak, Agnieszka. 2012. „Materiały legislacyjne w dyskursie interpretacyjnym z perspektywy brytyjskiej, amerykańskiej, francuskiej, szwedzkiej i polskiej”. W Konwergencja czy dywergencja kultur i systemów prawnych? Red. Oktawian Nawrot, Sebastian Sykuna, Jerzy Zjadło. Warszawa: C.H. Beck.

Dąbrowski, Stanisław. 2012. „Niezawisłość sędziów - gwarancje ustrojowe i zagrożenia”. Krajowa Rada Sadownictwa 2: 12-15.

Dworkin, Ronald. 1986. Law's Empire. London: Harvard University Press.

Dworkin, Ronald. 2011. Justice for Hedgehogs. London: Harvard University Press.

Fuller, Lon L. 1969. Morality of Law. New Haven, CT: Yale University Press.

Galewicz, Włodzimierz 2013. Status ludzkiego zarodka a etyka badań biomedycznych. Kraków: Wydawnictwo Uniwersytetu Jagiellońskiego.

Hart, Herbert L. A. 1961. The Concept of Law. Oxford: Clarendon Press.

Hart, Herbert L. A. 2014. „Nowe wyzwanie dla pozytywizmu prawniczego”. Archiwum Filozofii Prawa i Filozofii Spolecznej 2 (9): 5-20.

Hauser, Roman. 2015. „Konstytucyjna zasada niezawisłości sędziowskiej”. Zeszyty Naukowe Sadownictwa Administracyjnego 1: 9-23.

La Torre, Massimo. 2007. Constitutionalism and Legal Reasoning. Dordrecht: Springer.

Rocławska, Anna. 2015. „Czy polski sędzia wymaga od sędziów »dzielności etycznej«? Rozważania na tle ustawowego wymogu »nieskazitelności charakteru«". Ogrody Nauk i Sztuk 5: 99-110.

Saja, Krzysztof. 2015. Etyka normatywna między konsekwencjalizmem a deontologiq. Kraków: Universitas.

Skrzydło, Wiesław. 2013. „Komentarz do art. 178 Konstytucji Rzeczypospolitej Polskiej”. Konstytucja Rzeczypospolitej Polskiej. Komentarz. Warszawa: Lex a Wolters Kluwer business.

Solum, Lawrence. 2006. "Natural Justice". American Journal of Jurisprudence 51 (1): 65-105.

Tobor, Zygmunt. 2005. „Bezstronność sędziego”. Przegląd Sądowy 6: 3-15.

Tobor, Zygmunt. 2013. W poszukiwaniu intencji prawodawcy. Warszawa: Lex a Wolters Kluwer business.

Tobor, Zygmunt. 2015. „To do a great right, do a little wrong - rzecz o sędziowskich kłamstewkach". Przeglad Podatkowy 6: 15-22.

\section{Akty prawne}

Konstytucja Rzeczypospolitej Polskiej z dnia 2 kwietnia 1997 r. (Dz. U. 1997, Nr 78, poz. 483 ze zm.).

Ustawa z dnia 27 lipca 2001 r. - Prawo o ustroju sądów powszechnych (Dz. U. 2001, Nr 98, poz. $1070 \mathrm{ze} \mathrm{zm})$.

Zbiór Zasad Etyki Zawodowej Sędziów. Załącznik do uchwały nr 16/2003 Krajowej Rady Sądownictwa $\mathrm{z}$ dnia 19 lutego $2003 \mathrm{r}$.

\section{Orzecznictwo}

Postanowienie SA w Katowicach z 26 marca 2014 r. (II S 13/14, Portal Orzeczeń Sądu Apelacyjnego w Katowicach, opubl. 2.09.2014).

Wyrok SA w Katowicach z 17 stycznia 2013 r. (III AUa 915/12, Portal Orzeczeń Sądu Apelacyjnego w Katowicach, opubl. 29.03.2013).

Wyrok SA w Katowicach z 25 lipca 2013 r. (V ACa 251/13, Portal Orzeczeń Sądu Apelacyjnego w Katowicach, opubl. 29.11.2013). 
Wyrok SA w Katowicach z 13 lutego 2014 r. (II AKa 509/13, Portal Orzeczeń Sądu Apelacyjnego w Katowicach, opubl. 9.05.2014).

Wyrok TK z 24 czerwca 1998 r. (K 3/98, MP Nr 22, poz. 331).

Wyrok TK z 14 kwietnia 1999 r. (K 8/99, OTK ZU 1999/3, nr 3, poz. 31).

Wyrok TK z 7 listopada 2013 r. (K 31/12, Dz. U. 2013 r., poz. 1433)

\title{
Anna Rocławska
}

\section{APPLY THE LAW, AND DO WHAT YOU WANT? THE CONCEPT OF JUDICIAL INDEPENDENCE AND THE PROSPECTIVE OF A DEONTOLOGICAL MODEL OF JUDICIAL VIRTUES}

\begin{abstract}
This article explores judicial independence in light of a deontological model of virtues. It analyses judicial decisions and attitudes in the process of application of law, arguing that their aspirations to pursue judicial virtues are a secondary requirement against an overriding demand for abiding by law. The thesis is that judicial independence is a kind of a system presupposition that judges have some qualities which help them not only to fulfil their duties, but also to rise to ethical challenges during adjudication. The author recalls two theories of judicial reasoning in hard cases and tries to answer the question which of the theoretical models - by H. L. A. Hart or R. Dworkin - proposes a better characteristic of the judicial practice in the Polish justice system.
\end{abstract}

Keywords: independence, deontology, judicial virtues, theory of judging, Dworkin, Hart. 